no expense is spared in rendering their reproduction accurate and effective. But where the book is issued in a cheap and popular form this plan is less satisfactory. The illustrations in the chapter on tuberculosis might almost have been omitted, so vague is the idea of the tubercle bacillus they will convey to the uninitiated. But little exception can be taken to the subject-matter of the book. In the case of such a young and rapidly progressing branch of science no two experts will agree on the exact statements which should be included or omitted, as the case may be. On the whole, we think Dr. Woodhead has exercised a sound judgment in the selection of his materials. To the embryonic bacteriologist that part of the appendix which deals with the diagnosis of organisms will be of great service. There are a good many typographical errors, but in no case are these of prime importance. Dr. Woodhead has undoubtedly given us an excellent summary of the present state of knowledge on the subject, and, considering the many difficulties which have beset his path, may certainly be congratulated on the volume he has produced.

Zoology Notes for Students of Medicine and Science. By AleXANDER JoHnstone, F.G.S. Edinburgh : E. \& S. Livingstone. Pp. 388. -This useful little manual is divided into three parts. The first part is devoted to General Morphology, Histology and Physiology, and to the Protozoa and Vermes; the second part treats of Vermes, Mollusca, and Arthropoda ; and the third is occupied with the classes from Arthropoda to Man. The plan pursued is that a brief account of each class is given, then in succession the sub-classes and divisions are described, and finally a detailed account of some animal, as the anodonta amongst molluscs, and nephrops amongst crustacea. The descriptions, though short, are sufficiently accurate, but we venture to suggest to the anthor the advisability of giving the derivation of the uncouth appellations that have been bestowed on so many animals. For example, on the first page we open is the word Enteropneusta. A knowledge of the derivation would fix on the student's mind the remarkable feature of the position of its respiratory apparatus, which is scarcely emphasised enough in the text. The larva of the Balano. glossus - the Tornaria - is not referred to. We would further suggest a continuous paging throughout the book instead of in three parts as at present, and that an index should be added.

Die Blennorrhöe der Sexualorgane und ihre Complicationen. Nach dem Neuesten Wissenschaftlichen Standpunkte und Zablreichen eigener Studien und Untersuchungen. Dargestellt von Dr. ERNEST FINGER, Docent an der Universität in Wien. Zweite Auflage. Leipzig und Wien : Franz Deuticke. 1891.-This is the second edition of a work well known on the Continent for the care with which it has been prepared. The author has taken pains to bring this edition well up to date, and he has succeeded in making it one of the best treatises on this important subject in any language. The teaching is scientific, clear, an 1 precise, and the information full. There are nearly forty woodcuts-chiefly of instruments-scattered through the text, and five good lithographed plates at the end of the volume, which consists of just over 300 pages.

Ueber die Functionen der Grosshirnrinde. Gesammte Mittheilungen mit Anmerkungen von Hermans MUNK, Professor an der Universität zu Berlin. Pp. 320. Berlin: Angust Hirsch wald. 1890. - This volume constitutes a very serviceable résumé of the work that has been done in regard to the functions of the brain by the author during the last fourteen years. Dr. Munk reproduces no less than sixteen original memoirs which he has at different times read before various societies. $\mathrm{He}$ is in accord with most modern physiologists that localisation of function takes place in the brain, or, in other words, that there are certain regions of the cerebral cortex which are constructed to discharge certain definite functions, and he therefore admits a visual, an auditory, and an olfactory area, as well as an area or centre for common sensation. The volume before us not only contains the evidence on which he relies for the establishment of his views, but much polemical writing directed against Goltz and others who hold opiniors different from his own. It is a treatise that should be read by all those who are interested in the later development of neurological science.

Glimpses of Nature. By ANDREW WiLSON, F.R.C.S. Edin. London : Chatto and Windus.-Mr. Wilson, in the volume before us, makes no prețence of placing any fresh truths before his readers, or of giving a full or detailed statement concerning those topics of which he treats. There is, however, a charm about the work which will make it very acceptable to schoolboys, and implant in many youthful minds facts and fancies connected with the animate and inanimate world which will, in years to come, bring forth fruit abundantly.

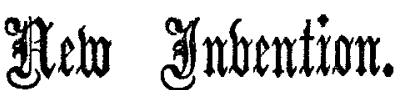

\section{AN IMPROVED CAUSTIC HOLDER.}

THE ordinary caustic holder for the pocket case has many drawbacks. Those made of beaten silver are expensive, and those of other materials are not durable; while in all the point is hidden, and when wanted is often found to have become corroded, and therefore inefficient. On these grounds I have asked Messrs. Hockin, Wilson, and Co. to construct one which, I venture to think, is without these

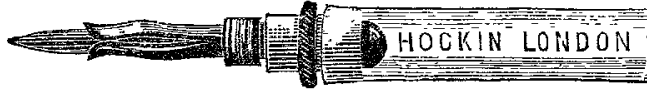

disadvantages, and shows distinct improvements on the older forms. The case itself is made of hardened glass tubing, divided in the centre into two compartments. Into each is fitted an ordinary silver gilt quill, with a reversible vulcanite mount, rendered easily fixable and air-tight by a rubber collar. Different points may be kept in the different compartments-e.g., nitrate of silver and sulphate of copper. The materials of which it is made are indestructible by the caustics, and inexpensive. Being made of glass, the condition of the points can always be seen at a glance, and the size is such that it exactly fits the ordinary pocket case. I have had one in use for some months now, and have found it satisfactory in all respects.
South Croydon.
H. Whitsy Phillips, M.D.

CotTage Hospital for Galashiels. - Last week it was resolved, at a public meeting held at Galashiels, to institute a Cottage Hospital for surgical and non-infectious cases of disease. It was announced that $f 1700$ had been subscribed, and that when the subscriptions amounted to $£ 2000$ a meeting of the subscribers would be called, to consider the arrangements for founding the hospital.

The London Medical Staff CorPs.-This corps was inspected at the Chelsea Barracks on Saturday by Deputy Surgeon-General Lewer. Surgeon-Major Morton had on parade 402 of all ranks, forming five companies (the establishment of the corps), and these were not equalised, each company standing on its own strength. The corps was remarkably steady during the line inspection, which Deputy Surgeon-General Lewer made of a detailed character. The march past was well executed, and the inspection concluded with an exbibition of hospital work and picking up and tending wounded men on the field of battle. The inspecting officer expressed his satisfaction with the effeient manner in which all had been performed. 